\title{
The Perception of Individual Investors towards the Performance of Mutual Funds
}

\author{
Mr. C. Praveen Kumar Reddy ${ }^{1}$, Prof. A. Sudhakar ${ }^{2}$ \\ ${ }^{I}$ Assistant Professor and Principal, OU PG College, Narsapur, Medak Dist.Telangana. \\ ${ }^{2}$ Department of Commerce, Dr. B. R. Ambedkar Open University Jubilee Hills, Hyderabad
}

\begin{abstract}
The mutual fund is a trust that pools the savings of a number of investors who share a common financial goal. This pool of money is invested in accordance with a stated objective. Mutual funds provide a mechanism to invest in the stock market without knowing the complexities of the stock market. Mutual funds provide the best option to the investors who have no knowledge of the stock market. Mutual Fund is the most suitable investment for the common man as it offers an opportunity to invest in a diversified, professionally managed basket of securities at a relatively low cost. The objectives of the study are to analyze the perception of individual investors towards the performance of mutual funds. The study aims at finding out the perception of the small and household investors towards investment in mutual funds in twin cities of Hyderabad and Secunderabad. The necessary data are collected by administering a structured questionnaire to 200 randomly selected investors based on simple random sampling method. Simple statistical tools like Cross Tables and Chi square test are used for analysing the data.
\end{abstract}

Keywords: Mutual Funds, Investors, Perception.

\section{Introduction}

Economic liberalization and globalization have brought a fervent environment for medium and small investors. There are a large number of small investors, who have the ability to save and make an investment in the corporate sector. The investment is very important to park the surplus fund of an individual for the purpose of earning additional income or capital appreciation or both.

People have plethora of investment options (with each option have its own distinct risk-return characteristic) not only to save money but also to see that it grows over a period of time. All investment avenues differ from one another and hence all are not equally attractive or distractive. In addition, investors are facing a problem in choosing the best alternative from the available investment options in the financial market. It is so because of lack of necessary information with regard to market fluctuations, time to analyze the market and expertise in the investment decisions. This has increased the necessity for tailor made instruments (investment options) that provide safety and security to investors. Hence the mutual funds are very suitable for the household sector and individual investors considering their lack of knowledge and expertise in financial market. There is a galore of mutual fund schemes available for investment for those who want to channelise their savings via mutual fund scheme ranging from money market mutual fund schemes to sector funds suiting well to the requirements of varied investors on the basis of risk return appetite of investors.

The investor has to consider various factors while making an investment decision, these are as follows: risks associated with the investment, tax benefits, liquidity, and marketability of the instruments, corporate earnings, stock affordability, dividend announcements, Price earnings ratio, Momentum effect, Contrarian effect, Investment behaviour of FIIs, firm's reputation, socially responsible investing, Current economic indicators, Opinion from family/friends/colleagues, broker's recommendation, and other professional advice. In this study very little research has been done to study the perception of individual investors towards the performance of mutual funds.

\section{Review of Literature}

Seema Sharma (2015) attempted to assess the overall investor perspective using a research design and she found that the Service quality and customer satisfaction have been conceptualized as distinct, but closely related constructs. There is a positive relationship between the two constructs. Tarak Paul (2014) studied the gap between the degree of expectation and the degree of perceived experience towards mutual fund investment from the viewpoint of customer communication dimension of marketing mix. It is being observed that Investors experienced lack of sufficient education required for investment and finds it difficult in understanding all the contents of the application form. The significant gap between the degree of expectation and degree of experience is indicative of the fact that there is a lot of scope for improvement in the area of customer communication. Mohindroo Amit and Singh Sureet (2013) opined that Mutual Funds, which have become an important portal for the small investors are also influenced by their financial behaviour. At an individual level, 
investors are unique and are a highly heterogeneous group. Hence, their fund/scheme selection behaviour also widely differs. This necessitates the Asset Management Companies (AMCs) to understand the fund/scheme selection/switching behaviour of the investors to design suitable products to meet the changing financial needs of the investors. Vasudevan. R (2013) endeavored to throw a light on the investors' perceptions of Mutual Fund risks. Understanding the requirements of investors of the Mutual Fund Companies has become necessary to accelerate the required pace of growth. A detailed analysis of risk perceptions of the investors was made in his study. Survey findings of his study have got significant implications that can be adopted by the Fund companies either by adding to the existing practices or by replacing. Rathnamani.V. (2013) concluded that many investors are preferred to invest in mutual fund in order to have high return at low level of risk, safety liquidity. Agrawal and Mini Jain (2013) an attempt is made to study mainly the investment avenue preferred by the investors of Mathura, and we have tried to analyze the investor's preference towards investment in mutual funds when other investment avenues are also available in the market. Sanjay Das (2012) conducted a study for identify the small investor's perceptions on mutual funds and the factors affecting small investors' towards investment in mutual funds in Assam by adopting convenience sampling, 250 respondents living in five different commercial towns of Assam. Gupta (1993) conducted a study with an objective to provide data on the investor preferences on mutual funds and other financial assets. The findings of the study were more appropriate at that time, to the policy makers and mutual funds to design the financial products for the future.

\section{Objective of the Study}

The objective of the research is to analyze the perception of individual investors towards the performance of mutual funds. The area under study includes twin cities of Hyderabad.

\section{Research Methodology}

To analyze the perception of investors towards mutual funds necessary data are collected by administering a structured questionnaire to 200 randomly selected investors based on simple random sampling method. Respondents are screened and the inclusion is purely on the basis of their knowledge about Financial Markets, especially the Mutual Fund.

The analysis of primary data collected through administering a structured questionnaire from investors have been made by making use of statistical tools like tabulation, percentage, ranking and Chi Square test etc.

\section{Summary of Findings}

The analysis reveals that the demographic profile (refer Table 1) of investors has a significant impact on the investors' decisions related to investments and particularly mutual fund investments. From the analysis it is noted that most of the sample respondents are male respondents belonging to the higher income class earning more than Rs. 3,00,000 a year. Most of the respondents are employed (42 percent), belonging to the age group of 31 years to 45 years. Majority of the respondents are under graduates ( 73 percent), married ( 73 percent), and saving below Rs. 20,000 per month (54 percent). Investors expressed high preference towards financial need (refer Table 2) to invest in long term savings (78.5 percent) with the investment objective of safe growth oriented investments (45.5 percent), but intend to play it somewhat safe for time period of 6-10 years (a time period of less than 5 years (59.5 percent)). Investors prefer bank deposits than other investment avenues and they are willing to take modest risk for higher returns in little volatility.

Most of the respondents prefer bank deposits (rank1) followed by equity shares, P.O Saving schemes and mutual funds among various investment avenues available to them. The investors are interested to invest in mutual funds based on a combination of return, safety, liquidity, profitability and tax benefits provided by the schemes. Growth oriented bank sponsored Indian mutual funds are highly preferred by the investors on the basis of quality of the product and services, risk and research factors. Brokers / agents are the main source of information about mutual funds. The investors are selecting the mutual funds for the benefits of convenience and professional management. The factors that influence the choice of Mutual Fund Organisations are past performance (rank 1) followed by suggestions. Further, the analysis reveals that the choice of the scheme is made based on objective of the fund (rank 1) and return on the investment and benefits.

\section{Conclusion}

The study concluded that Mutual fund investors are not satisfied with industry performance and services but are satisfied towards the investment opportunities in industry. All the investors strongly agreed that mutual funds are less risky compared to that of shares. Further, respondents strongly agree that mutual funds are more suitable to small investors for their positive high returns in the capital markets. Chi Square $\left(\chi^{2}\right)$ test results reveal that the investors' investment behaviour is similar within the demographic variables namely, age, occupation, education, marital status, income and saving groups except gender group. 


\section{Appendix}

\section{Profile of Investors}

The data required for the study was collected from 200 individual investors in mutual funds from Hyderabad twin cities. Their gender, marital status, age, education, occupation, monthly income and Monthly Savings have been analyzed and presented in Table 1.

Table 1: Profile of Investors

\begin{tabular}{|c|c|c|c|}
\hline Demographic Variables & Categories & No. of Respondents & Percent \\
\hline \multirow[t]{3}{*}{ Gender } & Male & 126 & 63.0 \\
\hline & Female & 74 & 37.0 \\
\hline & Total & 200 & 100.0 \\
\hline \multirow[t]{5}{*}{ Age } & Below 30years & 35 & 17.5 \\
\hline & $31-45$ years & 91 & 45.5 \\
\hline & $46-60$ years & 55 & 27.5 \\
\hline & Above 60 years & 19 & 9.5 \\
\hline & Total & 200 & 100.0 \\
\hline \multirow{4}{*}{ Occupation } & Business & 65 & 32.5 \\
\hline & Professional & 37 & 18.5 \\
\hline & Employed & 98 & 49.0 \\
\hline & Total & 200 & 100.0 \\
\hline \multirow[t]{4}{*}{ Education } & Up to Higher Secondary & 15 & 7.5 \\
\hline & Undergraduate & 146 & 73.0 \\
\hline & Postgraduate & 39 & 19.5 \\
\hline & Total & 200 & 100.0 \\
\hline \multirow[t]{3}{*}{ Marital Status } & Married & 174 & 87.0 \\
\hline & Unmanied & 26 & 13.0 \\
\hline & Total & 200 & 100.0 \\
\hline \multirow{5}{*}{ Monthly Income } & Below Rs. $1,00,000$ & 27 & 13.5 \\
\hline & Rs. $1,00,001-3,00,000$ & 67 & 33.5 \\
\hline & Rs. $3,00,000-6,00,000$ & 80 & 40.0 \\
\hline & Above Rs. $6,00,000$ & 26 & 13.0 \\
\hline & Total & 200 & 100.0 \\
\hline \multirow[t]{5}{*}{ Monthly Savings } & Below Rs.20,000 & 108 & 54.0 \\
\hline & Rs. $20,001-40,000$ & 63 & 31.5 \\
\hline & Rs. $40,000-80,000$ & 24 & 12.0 \\
\hline & Above Rs 80,000 & 5 & 2.5 \\
\hline & Total & 200 & 100.0 \\
\hline
\end{tabular}

Source: Primary Data

\section{Attitude towards Investment.}

For analysis of attitude of sample respondents towards investment, the required data is collected from 200 individual investors in mutual funds from Hyderabad twin cities. For the analysis the information is collected with regard to financial needs, investment objective, time horizon, willingness to take risk, fluctuation in the value of one's portfolio and experience in the field of investments.

Table 2: Attitude towards Investment

\begin{tabular}{|c|c|c|c|}
\hline Variables & Categories & No. of Respondents & Percent \\
\hline \multirow[t]{4}{*}{ Financial Needs } & Depend somewhat on investments for income and emergency needs & 19 & 9.5 \\
\hline & Depend on investments to serve only in an emergency & 24 & 12.0 \\
\hline & Devote investments to long - term savings. & 157 & 78.5 \\
\hline & Total & 200 & 100.0 \\
\hline \multirow{5}{*}{ Investment Objective } & First prionity for Income and second prionity for Growth & 34 & 17.0 \\
\hline & Balanced preference for income and growth & 27 & 13.5 \\
\hline & Basically, growth oriented, but intends to play it somewhat safe & 91 & 45.5 \\
\hline & Maximize growth, as income is not critical & 48 & 24.0 \\
\hline & Total & 200 & 100.0 \\
\hline \multirow[t]{5}{*}{ Time Horizon } & In 5 years & 13 & 6.5 \\
\hline & $6-10$ years & 153 & 76.5 \\
\hline & $11-15$ years & 31 & 15.5 \\
\hline & Above 15 years & 3 & 1.5 \\
\hline & Total & 200 & 100.0 \\
\hline \multirow{4}{*}{$\begin{array}{l}\text { Willingness to Take } \\
\text { Risk }\end{array}$} & Willing to take as much risk as possible & 14 & 7.0 \\
\hline & Willing to take modest risk & 157 & 78.5 \\
\hline & Avoid taking risk & 29 & 14.5 \\
\hline & Total & 200 & 100.0 \\
\hline \multirow{5}{*}{$\begin{array}{l}\text { Fuctuation in The } \\
\text { Value of Your Portfolio }\end{array}$} & Accept lower long run retums with maximum stability & 9 & 4.5 \\
\hline & Accept little volatility for higher retums. & 160 & 80.0 \\
\hline & Accept higher volatility as growth is the goal & 12 & 6.0 \\
\hline & Accept substantial volatility, as maximum appreciation is the goal & 19 & 9.5 \\
\hline & Total & 200 & 100.0 \\
\hline \multirow{5}{*}{$\begin{array}{l}\text { Experience in the field } \\
\text { of investments }\end{array}$} & Less than 5 years & 119 & 59.5 \\
\hline & $6-10$ years & 56 & 28.0 \\
\hline & $11-15$ years & 19 & 9.5 \\
\hline & $16-20$ years & 6 & 3.0 \\
\hline & Total & 200 & 100.0 \\
\hline
\end{tabular}

Source: Primary Data. 
The Perception of Individual Investors towards the Performance of Mutual Funds

Source: Primary Data

\begin{tabular}{|c|c|c|c|c|}
\hline \multicolumn{5}{|c|}{ Table. 3. Investments Statistics } \\
\hline \multirow[t]{2}{*}{ Investment Avenues } & $\mathbf{N}$ & Mean & Std. Deviation & Rank \\
\hline & Valid & & & \\
\hline Bank Deposits & 200 & 2.77 & 1.744 & 1 \\
\hline P.O. Saving Schemes & 200 & 3.77 & 1.820 & 3 \\
\hline Bonds and Debentures & 200 & 4.18 & 1.871 & 5 \\
\hline Equity Shares & 200 & 3.59 & 3.244 & 2 \\
\hline Mutual Funds & 200 & 3.82 & .935 & 4 \\
\hline Insurance Policies & 200 & 5.47 & 1.941 & 6 \\
\hline Real Estate & 200 & 5.89 & 1.832 & 7 \\
\hline Gold \& Silver & 200 & 6.52 & 1.349 & 8 \\
\hline
\end{tabular}

Table. 4. Degree of Safety

\begin{tabular}{|l|l|l|l|l|}
\hline Investment Avenues & N & Mean & Std. Deviation & \\
\cline { 1 - 1 } & Valid & & & Rank \\
\hline Bank Deposits & 200 & 5.00 & 0.000 & 1 \\
\hline P.O. Savings Scheme & 200 & 5.00 & 0.000 & 2 \\
\hline Bonds and Debentures & 200 & 3.01 & 0.071 & 3 \\
\hline Equity Shares & 200 & 2.17 & 0.377 & 8 \\
\hline Mutual Funds & 200 & 3.00 & 0.000 & 4 \\
\hline Insurance Policies & 200 & 3.00 & 0.000 & 5 \\
\hline Real Estate & 200 & 2.43 & 0.496 & 7 \\
\hline Gold \& Silver & 200 & 2.71 & 0.556 & 6 \\
\hline
\end{tabular}

Source: Primary Data

Table.5. Objective of selecting Mutual Funds (Statistics)

\begin{tabular}{|l|l|l|l|}
\hline \multirow{2}{*}{ Objective } & N & Mean & Std. Deviation \\
\cline { 2 - 4 } & Valid & & \\
\hline Return & 200 & 2.00 & 0.437 \\
\hline Stability & 200 & 2.71 & 0.656 \\
\hline Marketability Tax & 200 & 1.00 & 0.000 \\
\hline Benefit & 200 & 2.65 & 0.627 \\
\hline
\end{tabular}

Table.6: Investors' Preference towards Scheme Objective

\begin{tabular}{|l|l|l|l|l|}
\hline \multirow{3}{*}{ Scheme Objective } & N & Mean & Std. Deviation & Rank \\
\cline { 2 - 3 } & Valid & & & \\
\hline Growth & 200 & 1.33 & .480 & 1 \\
\hline Income & 200 & 3.49 & 1.835 & 4 \\
\hline Balanced & 200 & 3.29 & .823 & 3 \\
\hline ELSS & 200 & 4.61 & 1.151 & 5 \\
\hline Money Market & 200 & 5.88 & .891 & 6 \\
\hline Gilt & 200 & 6.61 & .664 & 7 \\
\hline Tax Saving & 200 & 2.81 & 1.063 & 2 \\
\hline
\end{tabular}

Source: Primary Data

Table.7. Factors Determining Success of Mutual Funds

Source: Primary Data

\begin{tabular}{|l|l|l|l|l|}
\hline \multirow{2}{*}{ Factors } & N & Mean & Std. Deviation & Rank \\
\cline { 2 - 3 } & Valid & & & \\
\hline Quality of service & 200 & 4.03 & 0.622 & 4 \\
\hline Suitability of product & 200 & 5.00 & 0.000 & 1 \\
\hline Research & 200 & 4.26 & 0.440 & 3 \\
\hline Risk orientation & 200 & 4.83 & 0.381 & 2 \\
\hline No: of investor service center & 200 & 3.73 & 0.768 & 5 \\
\hline
\end{tabular}

Table.8. Sources of Information on Mutual Fund

\begin{tabular}{|c|c|c|c|c|c|}
\hline & $\mathrm{N}$ & \multirow[t]{2}{*}{ Mean } & \multirow[t]{2}{*}{ Std. Deviation } & \multirow[t]{2}{*}{ Number of Responses } & \multirow[t]{2}{*}{ Rank } \\
\hline & Valid & & & & \\
\hline Brokers/ Agents & 200 & 1.00 & 0.000 & 200 & 1 \\
\hline Prospectus & 200 & 0.04 & 0.184 & 7 & 9 \\
\hline Advertisement & 200 & 0.23 & 0.419 & 45 & 6 \\
\hline Annual Reports & 200 & 0.36 & 0.480 & 71 & 5 \\
\hline Newspapers & 200 & 0.52 & 0.501 & 104 & 4 \\
\hline Magazines & 200 & 0.11 & 0.307 & 21 & 7 \\
\hline Friends and Relatives & 200 & 1.00 & 0.000 & 200 & 2 \\
\hline Television & 200 & 0.09 & 0.280 & 17 & 8 \\
\hline Mail & 200 & 0.00 & 0.000 & 0 & 10 \\
\hline Stores Display & 200 & 0.82 & 0.389 & 163 & 3 \\
\hline
\end{tabular}

Source: Primary Data 
Table.9. Benefits of Investing in Mutual Funds

Source: Primary Data

\begin{tabular}{|l|l|l|l|l|l|}
\hline \multirow{2}{*}{ Benefits } & N & Mean & Std. Deviation & $\begin{array}{l}\text { Number of } \\
\text { Responses }\end{array}$ & Rank \\
\cline { 2 - 5 } & Valid & & & 1 & 16 \\
\hline Portfolio diversification & 200 & .01 & .071 & 165 & 3 \\
\hline Tax Shelter & 200 & .83 & .381 & 13 & 10 \\
\hline Lower cost & 200 & .07 & .247 & 28 & 7 \\
\hline Liquidity of investment & 200 & .14 & .348 & 33 & 6 \\
\hline Assured allotment & 200 & .17 & .372 & 159 & 4 \\
\hline High Yielding & 200 & .80 & .405 & 200 & 1 \\
\hline Convenience & 200 & 1.00 & 0.000 & 9 & 13 \\
\hline Quality of service & 200 & .05 & .208 & 11 & 11 \\
\hline Innovation in Schemes & 200 & .06 & .229 & 0 & 17 \\
\hline Profitability & 200 & 0.00 & 0.000 & 10 & 12 \\
\hline Transferability & 200 & .05 & .218 & 8 & 15 \\
\hline Repurchase Facility & 200 & .04 & .196 & 111 & 5 \\
\hline Capital appreciation & 200 & .56 & .498 & 18 & 9 \\
\hline Loan Facility & 200 & .09 & .287 & 200 & 2 \\
\hline Professional Management & 200 & 1.00 & 0.000 & 19 & 8 \\
\hline Wide investment opportunities & 200 & .10 & .294 & 9 & 14 \\
\hline Transparent in operation & 200 & .05 & .208 & & 13 \\
\hline
\end{tabular}

Table.10. Factors Influencing the choice of MF Organization

\begin{tabular}{|l|l|l|l|l|}
\hline \multirow{2}{*}{ Factors } & $\mathrm{N}$ & \multirow{2}{*}{ Mean } & \multirow{2}{*}{ Std. Deviation } & \\
\cline { 2 - 5 } & Valid & & & Rank \\
\hline Goodwill & 200 & 4.70 & .462 & 3 \\
\hline Volume of business & 200 & 1.44 & 1.059 & 9 \\
\hline The Sector represented & 200 & 1.57 & 1.087 & 8 \\
\hline Investor services & 200 & 3.51 & .501 & 5 \\
\hline Past performance & 200 & 5.00 & 0.000 & 1 \\
\hline Infrastructure & 200 & 3.59 & .834 & 4 \\
\hline Suggestions & 200 & 4.85 & .363 & 2 \\
\hline Background Experience & 200 & 1.69 & 1.222 & 7 \\
\hline Investment Philosophy \& Methodology & 200 & 2.25 & 1.482 & 6 \\
\hline
\end{tabular}

Source: Primary Data

Table.11. Factors Influencing the choice of MF Scheme

\begin{tabular}{|l|l|l|l|l|}
\hline & N & Mean & Std. Deviation & \multirow{2}{*}{ Rank } \\
\cline { 1 - 2 } & Valid & & \\
\hline Capital Appreciation & 200 & 4.24 & .428 & 6 \\
\hline Objective of the fund & 200 & 5.00 & 0.000 & 1 \\
\hline Return on Investment & 200 & 5.00 & 0.000 & 2 \\
\hline Tax benefit & 200 & 4.39 & .488 & 3 \\
\hline Liquidity & 200 & 4.31 & .462 & 4 \\
\hline Safety & 200 & 4.30 & .457 & 5 \\
\hline Loan facility & 200 & 3.64 & .483 & 7 \\
\hline Convenience of reinvestment & 200 & 3.64 & .771 & 8 \\
\hline Fund Managers Background & 200 & 1.53 & 1.143 & 9 \\
\hline Early Bird Incentive & 200 & 1.49 & 1.037 & 10 \\
\hline
\end{tabular}

Source: Primary Data

Table.12. Degree of agreement relating to Mutual Funds (Statistics)

\begin{tabular}{|l|l|l|l|}
\hline Specific Attitude Statements & $\mathrm{N}$ & Mean & Std. Deviation \\
\hline & Valid & & \\
\hline Investing in funds is less risky compared to shares. & 200 & 5.00 & 0.000 \\
\hline $\begin{array}{l}\text { Mutual Funds are more suitable to small investors who are otherwise hesitant } \\
\text { about entering into the capital market. }\end{array}$ & 200 & 5.00 & 0.000 \\
\hline $\begin{array}{l}\text { Risk and return characteristics of Indian MFs are not in conformity with their } \\
\text { stated objectives. }\end{array}$ & 200 & 3.90 & .605 \\
\hline $\begin{array}{l}\text { Investing in funds is much better in terms of returns than depositing money in } \\
\text { banks. }\end{array}$ & 200 & 3.42 & .828 \\
\hline Growth schemes are highly preferred to income schemes. & 200 & 4.71 & .455 \\
\hline Mutual Fund investing gives a definite positive return. & 200 & 4.79 & .408 \\
\hline $\begin{array}{l}\text { MF returns and Principal are fully protected and guaranteed by the } \\
\text { Association of Mutual Funds (AMFI) }\end{array}$ & 200 & 3.64 & .673 \\
\hline $\begin{array}{l}\text { Bank sponsored Mutual Funds give a definite positive return which is greater } \\
\text { than Bank fixed deposit rate for a similar period. }\end{array}$ & 200 & 2.55 & .800 \\
\hline Entry and exit out of Mutual Funds is easy & 200 & 2.37 & .636 \\
\hline Due to professional investment, a good return can be expected of Mutual & 200 & 4.24 & .428 \\
\hline
\end{tabular}




\begin{tabular}{|l|l|l|l|}
\hline Funds & & & \\
\hline There are many MF schemes to meet the varied needs of investors & 200 & 3.95 & .416 \\
\hline AMFI protects the interests of MF industry and the unit holders & 200 & 3.87 & .337 \\
\hline
\end{tabular}

Source: Primary Data

\section{References.}

[1] Seema Sharma, "ELSS Mutual Funds in India: Investor Perception and Satisfaction”, International Journal of Finance and Accounting, 4(2): pp. 131-139, 2015. DOI: 10.5923/j.ijfa.20150402.03.

[2] Tarak Paul, "Customer Communication Dimension of Marketing Mix- A Review of Gap between Mutual Fund Investors' Expectation and Experience”, Scholars Journal of Economics, Business and Management, 2014; 1(5).

[3] Mohindroo Amit, and Singh Sureet, "Factors affecting investment in mutual funds - An exploratory study", SAARJ Journal on Banking and Insurance Research, Volume: 2, Issue: 3, p1-24, 2013.

[4] Vasudevan. R, “Investors' Perceptions of Mutual Fund Risks an Empirical Study”, “SAMZODHANA" Journal of Management Research", Vol 1 Issue 1 September 2013.

[5] Rathnamani, V., “Investor's Preferences towards Mutual Fund Industry in Trichy”, IOSR Journal of Business and Management, Vol. 6 (6): pp. 48-55, 2013.

[6] Gaurav Agrawal and Mini Jain, “Investor's Preference towards Mutual Fund in Comparison to other Investment Avenues", Journal of Indian Research (ISSN: 2321-4155), Vol.1, No.4, October-December, 2013, pp. 115-131.

[7] Vasudevan, R and Peermohaideen, “Investors' Perceptions of Mutual Fund Risks an Empirical Study”, TRANS Asian Journal of Marketing and Management Research, Vol.1 Issue 3-4, pp 33- 42, 2012

[8] Yesh Pal Davar and Suveera Gill (2007), "Investment Decision Making: An empirical study of perceptual view of Investors", Indian Institute of Management, Lucknow Journal, Vol. 6, No. 2, 2007, pp. 115-135.

[9] Syed Tabassum Sultana (2010), “An empirical study of Indian individual investor's behaviour", Global Journal of Finance and Management, Volume 2, Number 1, pp. 19-33.

[10] Mohindroo Amit, and Singh Sureet, "Factors affecting investment in mutual funds - An exploratory study", SAARJ Journal on Banking and Insurance Research, Volume: 2, Issue: 3, p1-24, 2013.

[11] Shantanu Mehta and Charmi Shah, "Preference of Investors for Indian Mutual Funds and its Performance Evaluation", Pacific Business Review International, Volume 5 Issue 3, pp 62-76, 2012

[12] Tarak Paul and Ekta Garodiam, “Equity Investors' Expectation And Experience - A Gap Analysis” IRJC, Asia Pacific Journal of Marketing and Management Review, Vol.1 No. 3, November 2012.

[13] Jensen \& Michael.C, “The performance of Mutual funds in the period 1945-1964”, Journal of Finance, 23: pp.389-416, 1968.

[14] Sharpe William F, “Mutual fund performance”, Journal of Business, 39, pp.119-138, 1966.

[15] J. Treynor and K. Mazuy, Can Mutual Funds Outguess the Market?, Harvard Business Review, 44 (1966), 131-136.

[16] E. Tsionas and N. Philippas, Market timing and selectivity: A random coefficient model for Greek mutual funds, In: European Accounting Association, 24th Annual Congress, Athens, Greece, April 2001.

[17] Agrawal, Deepak and Patidar, Deepak, A Comparative Study of Equity Based Mutual Fund of Reliance and HDFC (October 10, 2009). Prabandhan \& Taqniki, Vol. 3, pp. 145-154, October 2009. 